University for Business and Technology in Kosovo

UBT Knowledge Center

UBT International Conference

2018 UBT International Conference

Oct 27th, 9:00 AM - 10:30 AM

\title{
Isolation and characterization of natural protease producers of Bacillus spp. from Soil samples
}

\author{
Ylberinë Baliu \\ University of Mitrovica \\ Bahtir Hyseni \\ University of Mitrovica \\ Shkëlqim Hyseni \\ University of Mitrovica \\ Aida Rushiti \\ University of Mitrovica \\ Flora Ferati \\ University of Mitrovica
}

See next page for additional authors

Follow this and additional works at: https://knowledgecenter.ubt-uni.net/conference

Part of the Food Science Commons

\section{Recommended Citation}

Baliu, Ylberinë; Hyseni, Bahtir; Hyseni, Shkëlqim; Rushiti, Aida; Ferati, Flora; Rexhepi, Fatos; Morina, Rifat; Hajdini, Sabri; and Nikerel, Emrah, "Isolation and characterization of natural protease producers of Bacillus spp. from Soil samples" (2018). UBT International Conference. 175.

https://knowledgecenter.ubt-uni.net/conference/2018/all-events/175

This Event is brought to you for free and open access by the Publication and Journals at UBT Knowledge Center. It has been accepted for inclusion in UBT International Conference by an authorized administrator of UBT Knowledge Center. For more information, please contact knowledge.center@ubt-uni.net. 


\section{Presenter Information}

Ylberinë Baliu, Bahtir Hyseni, Shkëlqim Hyseni, Aida Rushiti, Flora Ferati, Fatos Rexhepi, Rifat Morina, Sabri Hajdini, and Emrah Nikerel 


\title{
Isolation and characterization of natural protease producers of Bacillus spp. from Soil samples
}

\author{
Ylberinë Baliu ${ }^{1}$, Bahtir Hyseni ${ }^{1,2}$, Shkëlqim Hyseni ${ }^{1}$, Aida Rushiti ${ }^{1}$, Flora Ferati ${ }^{1}$, \\ Fatos Rexhepi ${ }^{1}$, Rifat Morina ${ }^{1}$, Sabri Hajdini ${ }^{1}$, Emrah Nikerel ${ }^{2 *}$ \\ ${ }^{1}$ University of Mitrovica, Dept of Engineering and Food Technology, Mitrovica, Kosovo \\ ${ }^{2}$ Yeditepe University, Genetics and Bioengineering Dept, Istanbul, Turkey \\ Corresponding author: Emrah Nikerel, email: emrah.nikerel@yeditepe.edu.tr
}

\begin{abstract}
Proteases are group of enzymes catalyzing the hydrolysis of proteins. Proteases are considered as commercially most significant among industrial enzymes with wide range of applications in several industries like food, detergent, textile, pulp and paper, and pharmaceutics. Enzymes can be produced by plants, animals or microorganisms, the latter being the dominant host, typically with modified features via recombinant DNA technology for high enzyme production. However, for e.g. food industry, the use of genetically modified microorganisms is not preferred, therefore isolation of new, wild-type microorganism for enzyme production is highly desired. Here we present the results of screening, isolation and characterization of new Bacillus spp. for protease production from soil samples from different areas in Kosovo. Soil samples were divided into four different groups according to their origin: (i) isolates from areas polluted by heavy industry, (ii) isolates from high altitude, (iii) loess sample near thermal water springs, and (iv) arable land. Strains with better protease activity, when compared to the reference strain is obtained.
\end{abstract}

Keywords: Industrial biotechnology, Enzymes, Protease, Isolation, Screening, FTIR.

\section{Introduction}

Enzymes are specialized proteins accelerating biochemical reactions[1], in a highly substrate-specific manner, also functioning in extreme conditions and are considered to be "green chemicals" as being environmentally friendly by lowering the activation energy, being biodegradable[2]. Overall, and their role in industrial biotechnology is well established and these are highly desired.

Proteases are considered important industrially enzymes with around $60 \%$ of enzyme market. Several industries like food, textile, detergent, pulp and paper, and pharmaceutical industries, increased their application of protease in their processes [3]. Food industry is one of the major users of proteases, whereby these are used in many hydrolyzing processes such as in infant food production, juice fortification, 
milk clotting, sausage making etc. [3]. Proteases are produced by animals, plants or microorganisms, yet typically microbes (bacteria, yeast and fungi) are the dominantly preferred producers. In particular, if the production host is an extremophile, the resulting product typically operates in extreme conditions or has longer shelf life. Such extremophiles, in turn, are isolated from extreme environments such as hot water springs, industrially polluted or high salt content areas [4]. Bacterial proteases mostly from Bacillus spp. and usually are neutral or alkaline proteases, suitable for food industry since neutral proteases generate fewer bitter compounds.

Bacillus spp. is soil dwelling, aerobic, endospore-forming gram positive rodshaped organism, urease, catalase, gelatin liquefaction positive, while gas, indole, methyl red negative[5]. Bacillus spp are classified as GRAS (Generally Regarded as Safe), and they are safely applied as food ingredients as well as probiotics [6]. Natto, a soybean fermented food is one of the oldest recorded process were Bacillus subtilis is used for soy protein hydrolyzation [7].

Considering the industrial importance of proteases, the aim of this work is to isolate and characterize novel Bacillus spp. capable for high level protease production from different soil samples.

\section{Materials and methods}

\subsection{Samples and growth media}

Soil samples from four different environments in Kosovo as (i) areas polluted by heavy industry, (ii) high altitude, (iii) loess sample near thermal water springs, and (iv) arable land (Fig. 1), were collected and stored at $+4^{\circ} \mathrm{C}$ until the screening was performed. During the sampling aseptic conditions were applied sampling equipment's were flame sterilized and placed in sterile plastic bags. All chemicals were at least laboratory grade.

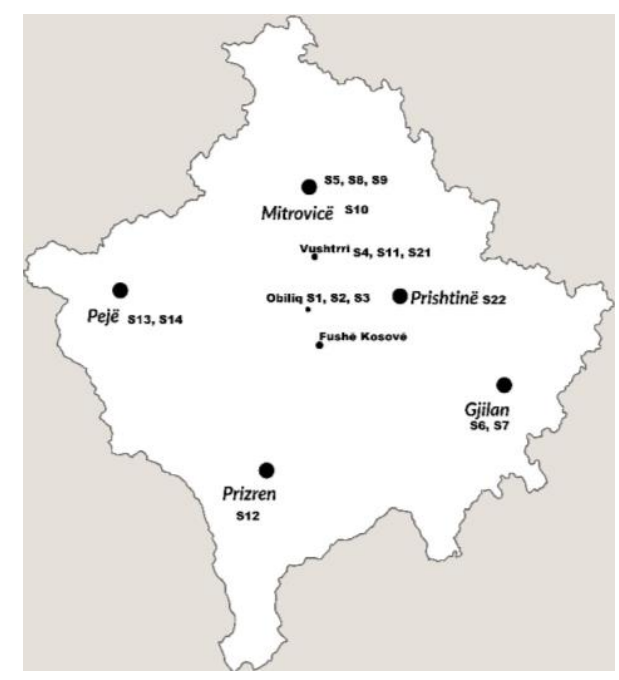

Fig.1 Sampling locations: Contaminated area (byproduct of the lead refining process, or from slaughter house) (S1, S2, S5, S11, S20, S21, S22), High altitude (S8, S9, S12), Thermal spring water loess (S6, S7, S13, S14), Arable land (S3, S4, S10) 


\subsection{Preparation of soil samples}

One gram of soil sample was diluted in $9 \mathrm{ml}$ of sterile saline solution and mixed for $14 \mathrm{~min}$ at $150 \mathrm{rpm}$. Then, samples were diluted until $10^{-6} .0 .1 \mathrm{ml}$ of the samples $10^{-3}-10^{-6}$ are spread on the skim milk agar. Plates were incubated at $37^{\circ} \mathrm{C}$ for $24 \mathrm{~h}$. Colonies with a clear zone were streaked into a fresh agar for further investigation [8].

\subsection{Characterization of Bacillus spp. colonies, Gram staining and Catalase tests}

Colonies are examined using microscope, in search for rod shape colonies, and these are selected as potential Bacillus spp. Gram staining procedure was applied based on the work of Bartholomew et al., [9]. Prepared bacterial smears from grown colonies for $18 \mathrm{~h}$ were firstly stained with crystal violet for $1 \mathrm{~min}$ then gram iodine solution for $30 \mathrm{sec}$., following by decolorization with $96 \%$ alcohol for $5 \mathrm{sec}$. and washing with water then counterstaining safranin solution was applied for $20 \mathrm{sec}$. The last step is washing with water and drying.

Single colony was carefully placed in the microscope glass slide. One droplet of 3\% peroxide was added in the slide above the colony and the slide was examined against a black background for catalase activity examination[10].

\subsection{Protease activity measurement}

Protease activity of each colony was measured in duplicate date, where colonies were inoculated on $1 \%$ skimmed milk agar with sterile wood toothpick and the diameter was measured in mm using image processing software.

\subsection{Fourier Transform Infrared Spectroscopy}

Advanced methods that are used for bacteria characterization are: Fourier Transform Infrared spectroscopy (FTIR) [11], determination of fatty acid profile of the cell wall using Gas chromatography (GC)[12], 16S sequencing[13]. Among those, infrared spectroscopy is a technique based on the vibrations of the atoms of a molecule. An infrared spectrum is commonly obtained by passing infrared radiation through the sample and determining what fraction of the incident radiation is absorbed at a particular energy. $18 \mathrm{~h}$ colonies grown in nutrient agar $1 \%$ skim milk medium smear between two transparent $\mathrm{KBr}$ plates, subsequently placed under the infrared light source between 1000-4000 $\mathrm{cm}^{-1}$. Peaks between $1000-2000 \mathrm{~cm}^{-1}$ were characterizing peaks for Bacillus spp.

\section{Results}

Fifty-one samples are initially collected and screened for extracellular protease activity. Among those, 29 colonies were identified as protease producers. The resulting colonies were compared with model organism $B$. subtilis 168 Fig. 2 Left panel. Based on appearance, 28 colonies are identified as potential Bacillus spp. 
(Table 1). Further analysis under microscope and Gram staining resulted that, 20 of them have morphological characteristics of Bacillus spp. (Fig. 2 Middle panel). Lastly, catalase test allowed identification of 19 colonies as potential B. subtilis (Fig. 2 Right panel). Finally, FTIR analysis reduced the list down to only 9 colonies as $B$. subtilis. Fig. 3 represents selected FTIR profiles. Among the analyzed samples, S6-4, isolated from thermal spring water is found to be a protease producer superior to the reference strain.
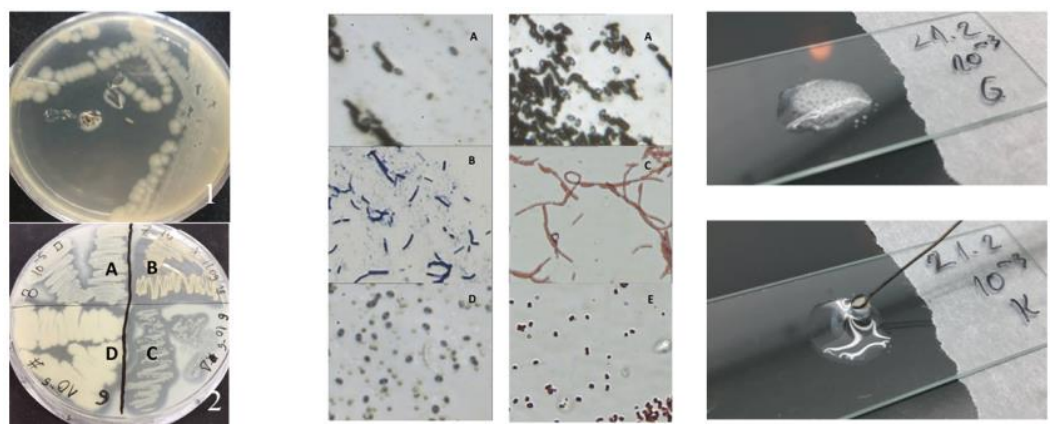

Fig. 2 Left panel: Different colors of colonies in the $1 \%$ skim milk agar;1) $B$. sub. 168, model organism; 2) A, C- white colonies, D- Floral white colonies, B- Yellow colonies. Middle panel Microscopic view of the fixed cells stain according to Gram, A- B. sub. 168 B- rod shape violet to blue Gram positive; C- rod shape red color Gram negative; D- Cocci violet to blue Gram positive; E- Cocci Gram negative. Right panel Catalase test with 3\% hydrogen peroxide; Topbubbles shows catalase positive; Bottom- no bubbles shows catalase negative.

It should be noted that, although S7-1 has the highest protease activity, it is a gramnegative bacterium with yellow color which is not characteristic of Bacillus spp., also with different FTIR profile (Fig. 3).

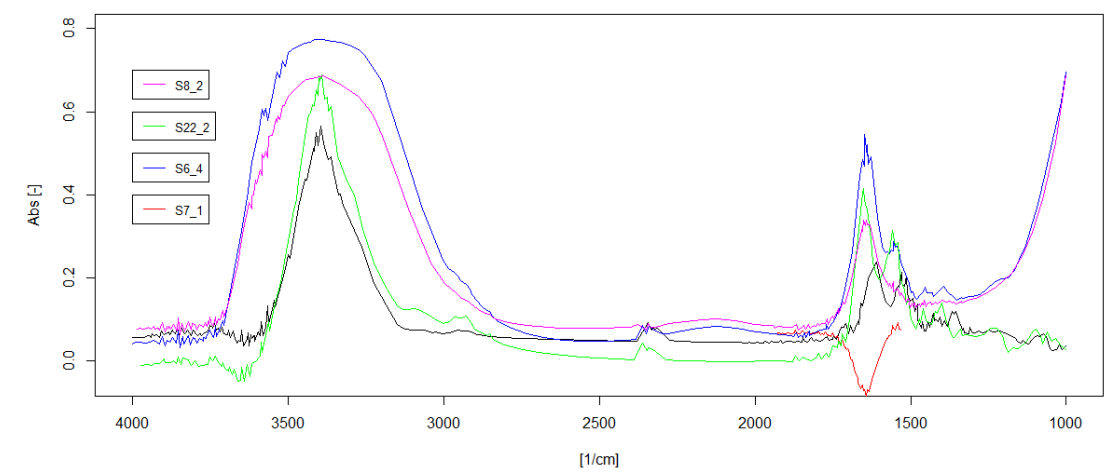

Fig. 3 FTIR results for colonies with highest resemblance to B. subtilis 168 


\section{Summary}

This work reports the results of isolation (from different locations in Kosovo), screening (based on microbiological, morphological and enzymatic tests), and characterization (based on FTIR analysis) of new Bacillus strains for production of an industrially significant enzyme, protease. We report novel strains with better protease production when compared to the reference, illustrating that natural sources are to be exploited by using proper techniques.

Acknowledgments. This work is funded by The Ministry of Education and Science and Technology of Kosovo with project number 2-3970-3.

\section{References}

1. Singh, P., A. Rani, and N. Chaudhary, Isolation and characterization of protease produsing Bacillus sp from soil. International Journal of Pharma Scinences and Research, 2015. 6(04): p. 7.

2. Gavrilescu, M. and Y. Chisti, Biotechnology-a sustainable alternative for chemical industry. Biotechnol Adv, 2005. 23(7-8): p. 471-99.

3. Gupta, R., Q.K. Beg, and P. Lorenz, Bacterial alkaline proteases: molecular approaches and industrial applications. Appl Microbiol Biotechnol, 2002. 59(1): p. 15-32.

4. Wang, X.C., et al., Improving production of extracellular proteases by random mutagenesis and biochemical characterization of a serine protease in Bacillus subtilis S1-4. Genet Mol Res, 2016. 15(2).

5. $\quad$ Elsholz, A.K.W., et al., Functional Diversity of AAA+ Protease Complexes in Bacillus subtilis. Front Mol Biosci, 2017. 4: p. 44.

6. $\quad$ Lefevre, M., et al., Safety assessment of Bacillus subtilis CU1 for use as a probiotic in humans. Regul Toxicol Pharmacol, 2017. 83: p. 54-65.

7. Kubo, Y., et al., Phylogenetic analysis of Bacillus subtilis strains applicable to natto (fermented soybean) production. Appl Environ Microbiol, 2011. 77(18): p. 6463-9.

8. Pant, G., et al., Production, optimization and partial purification of protease from Bacillus subtilis. Journal of Taibah University for Science, 2015. 9(1): p. 50-55.

9. Bartholomew, J.W. and H. Finkelstein, Relationship of cell wall staining to gram differentiation. Journal of bacteriology, 1957. 75(1): p. 8.

10. Taylor, W.I. and D. Achanzar, Catalase test as an aid to the identification of enterobacteriaceae. Applied Microbiology, 1972. 24(1): p. 4.

11. Griffiths, M.W., S.F. Lin, and H. Schraft, Identification of Bacillus cereus by Fourier Transform Infrared Spectroscopy $\{F T I R\}$. Journal of food protection 1998. 61(7): p. 3.

12. Dick, R.P. and M.E. Schutter, Comparison of Fatty Acid Methyl Ester (FAME) Methods for Characterizing Microbial Communities. Soil. Sci. Soc. Am. J., 2000. 64: p. 10. 
13. Hayat, R., et al., Characterization and identification of compost bacteria based on 16S rRNA gene sequencing. Annals of Microbiology, 2012. 63(3): p. 905-912.

Table 1Morphological characteristics of colonies and protease activity

\begin{tabular}{|c|c|c|c|c|c|c|c|c|}
\hline Colony & Shape & Color & $\begin{array}{l}\text { Gram } \\
\text { Staining }\end{array}$ & $\begin{array}{l}\text { Catalase } \\
\text { Assay }\end{array}$ & FTIR, P1 & FTIR, P2 & FTIR, P3 & $\begin{array}{l}\text { Halo diameter } \\
\text { in skim milk } \\
\text { assay }\end{array}$ \\
\hline S3-1 & Cocci & Yellow & + & + & 1749.4 & 1633.0 & 1539.2 & 3.65 \\
\hline S3-2 & Rod & White & + & + & 1749.4 & 1633.0 & 1539.2 & 2.28 \\
\hline S5-1 & Rod & White & - & + & ND & ND & ND & 2.95 \\
\hline S6-1 & Rod & White & - & + & ND & ND & ND & 0.35 \\
\hline S6-2 & Rod & F- White & + & + & ND & ND & ND & 2.87 \\
\hline S6-3 & Rod & White & - & + & ND & ND & ND & 4.85 \\
\hline S6-4 & Rod & F- White & + & + & 1749.4 & 1653.0 & 1539.2 & 5.51 \\
\hline S7-1 & Rod & Yellow & - & + & 1747.5 & 1653.0 & 1541.1 & 7.14 \\
\hline S8-1 & Rod & White & + & + & 1747.5 & 1653.0 & 1539.2 & 0.42 \\
\hline S8-2 & Rod & White & - & + & ND & ND & ND & 3.31 \\
\hline S8-3 & Rod & White & + & + & 1749.4 & 1651.1 & 1541.1 & 1.56 \\
\hline S8-4 & Rod & White & + & + & 1734.9 & 1651.0 & 1541.1 & 0.39 \\
\hline S9-2 & Rod & White & + & + & ND & ND & ND & 0.60 \\
\hline S10-3 & Rod & White & + & + & ND & ND & ND & 2.68 \\
\hline S10-4 & Rod & White & - & + & 1747.5 & 1653.0 & 1543.1 & 3.59 \\
\hline S10-5 & Rod & White & + & - & 1747.5 & 1653.0 & 1543.1 & 0.78 \\
\hline S11-1 & Rod & F- White & + & + & ND & ND & 1543.1 & 0.71 \\
\hline S11-4 & Rod & White & + & + & ND & ND & ND & 2.76 \\
\hline S12-1 & Rod & White & + & + & ND & ND & ND & 1.00 \\
\hline S13-1 & Rod & White & + & + & ND & ND & ND & 1.13 \\
\hline S13-2 & Rod & White & + & + & ND & ND & ND & 0.11 \\
\hline S20-1 & Cocci & Green & + & + & 1749.4 & 1653.0 & 1539.2 & 0.89 \\
\hline S20-2 & Rod & White & + & + & ND & ND & ND & 1.09 \\
\hline S21-1 & Rod & White & + & + & 1749.4 & 1651.1 & 1539.2 & 3.51 \\
\hline $\mathrm{S} 21-2$ & Rod & White & + & + & 1759.1 & 1732.1 & 1549.9 & 2.45 \\
\hline $\mathrm{S} 21-3$ & Rod & White & + & + & ND & ND & ND & 2.11 \\
\hline S22-1 & Cocci & White & + & + & 1732.1 & 1653.0 & 1541.1 & 0.12 \\
\hline S22-2 & Rod & White & + & + & 1732.1 & 1653.0 & 1541.1 & 1.16 \\
\hline $\mathrm{S} 22-3$ & Rod & White & + & + & 1739.8 & 1653.0 & 1541.1 & 0.70 \\
\hline Bsubt.168 & Rod & White & + & + & 1734.0 & 1653.0 & 1543.1 & 3.61 \\
\hline
\end{tabular}

